\title{
Ribonuclease E organizes the protein interactions in the Escherichia coli RNA degradosome
}

\author{
Nathalie F. Vanzo, ${ }^{1}$ Yeun Shan $\mathrm{Li}^{2}{ }^{2}$ Béatrice Py, ${ }^{2,3}$ Erwin Blum, ${ }^{2}$ Christopher F. Higgins, ${ }^{2,4}$ \\ Lelia C. Raynal, ${ }^{1}$ Henry M. Krisch, ${ }^{1}$ and Agamemnon J. Carpousis ${ }^{1,5}$ \\ ${ }^{1}$ Laboratoire de M icrobiologie et Génétique M oléculaire, UPR 9007, Centre N ational de la Recherche Scientifique (CN RS), \\ 31062 Toulouse Cedex, France; ${ }^{2} \mathrm{~N}$ uffield Department of Clinical Biochemistry and Imperial Cancer Research Fund \\ Laboratories, Institute of M olecular M edicine, John Radcliffe Hospital, University of Oxford, Oxford OX3 9DS, UK
}

The Escherichia coli RNA degradosome is the prototype of a recently discovered family of multiprotein machines involved in the processing and degradation of RNA. The interactions between the various protein components of the RNA degradosome were investigated by Far Westem blotting the yeast two-hybrid assay, and coimmunopurification experiments. Our results demonstrate that the carboxy-terminal half (CTH) of ribonuclease E (RNase E) contains the binding sites for the three other major degradosomal components, the DEAD-box RNA helicase RhIB, enolase, and polynucleotide phosphorylase (PNPase). The CTH of RNase E acts as the scaffold of the complex upon which the other degradosomal components are assembled. Regions for oligomerization were detected in the amino-terminal and central regions of RNase E. Furthermore, polypeptides derived from the highly charged region of RNase E, containing the RhlB binding site, stimulate RhlB activity at least 15-fold, saturating at one polypeptide per RhlB molecule. A model for the regulation of the RhIB RNA helicase activity is presented. The description of RNase $E$ now emerging is that of a remarkably complex multidomain protein containing an amino-terminal catalytic domain, a central RNA-binding domain, and carboxy-terminal binding sites for the other major components of the RNA degradosome

[Key Words: RNA degradation; ribonuclease E; protein-protein interactions; RNA degradosome; DEAD-box RNA helicase; RhIB activation]

Received May 18, 1998; revised version accepted June 26, 1998.

mRN A decay in Escherichia coli is mediated by the combined action of endo- and exoribonucleases (for review, see Belasco and Higgins 1988; Ehretsmann et al. 1992; Nierlich and Murakawa 1996). Two of the principal nucleases, ribonuclease $E$ (RN ase E) and polynucleotide phosphorylase (PN Pase), have been shown to be components of a multienzyme complex, the RN A degradosome (Carpousis et al. 1994; Py et al. 1994, 1996). Although RN ase $E$ and PN Pase are functional by themselves, their association in a complex could coordinate their activities in the degradation of RNA (Cohen 1995; Xu and Cohen 1995; Braun et al. 1996). The two other major components of the degradosome were identified as enolase and the DEAD-box helicase RhIB (Miczak et al. 1996; Py et al. 1996). In vitro experiments have shown that RhIB in the degradosome can facilitate PN Pase-mediated degradation presumably by unwinding RNA stem-loop structures (Py et al. 1996; E. Blum, A.J. Car-

Present addresses: 3Institut de Chimie Bactérienne, Centre National de la Recherche Scientifique, UPR 9043, 13403 Marseille Cedex, France; ${ }^{4}$ Medical Research Council Clinical Sciences Centre, Imperial College School of Medicine, Hammersmith Hospital, London W12 ONN, UK. ${ }^{5}$ Corresponding author.

E-MAIL Carpousi@ibcgibiotoul.fr; FAX (033) 05.61.33.58.86. pousis, and C.F. Higgins, in prep.). Enolase is a glycolytic enzyme whose role in mRNA decay still remains to be elucidated. Plausible functions include the regulation of degradosome activity in response to growth conditions.

Besides the major components, preparations of the RNA degradosome contain several other proteins present in nonstoichiometric amounts. These include the chaperones DnaK and GroEL, known to aid protein folding, that could have a role in the assembly of the RN A degradosome (Miczak et al . 1996; Bl um et al. 1997). Polyphosphate kinase, which can reversibly catalyze the formation of polyphosphate from ATP, is another enzyme associated with the degradosome. It has been suggested that the regulation of polyphosphate levels may be involved in controlling the activity of the RNA degradosome (Blum et al. 1997).

Recently, several other degradosome-like complexes have been identified in eukaryotic cells. A PN Pase homolog is part of a multiprotein complex implicated in the regulation of chloroplast message stability (Hayes et al. 1996). The mtEXO complex and the exosome, involved in RNA processing and degradation, are two other complexes described in yeast and its mitochondria ( $M$ argossian et al. 1996; Mitchell et al. 1997). One of the ri- 
bonucleases found in the exosome has a human homolog, suggesting that a similar complex could al so exist in animal cells. In addition to the $3^{\prime} \rightarrow 5^{\prime}$ exoribonuclease activity, the mtEXO complex contains a putative DExHbox helicase. Similarly, two ATP-dependent RN A helicases may be associated with the exosome (Anderson and Parker 1998; de la Cruz et al. 1998). The identification of multiprotein complexes in bacteria, plants, and yeast suggests that assemblies of ribonucleases with other enzymes such as RN A helicases could be a common feature in RNA processing and decay.

E. coli RN ase E is a large protein containing 1061 amino acids (Cormack et al. 1993; Casarégola et al. 1992). The amino-terminal half of the protein contains the catalytic site for the single-strand-specific endonuclease (EN DO) activity (Taraseviciene et al . 1995; M cDowall and Cohen 1996). It was discovered recently that this region also contains a $3^{\prime}$ polyadenylate or polyuridylate nuclease (PAUN) activity (Huang et al. 1998). The carboxy-terminal half $(\mathrm{CTH})$ of RN ase $\mathrm{E}$ is characterized by regions of different amino acid composition including proline-rich, highly charged, and acidic segments (Claverie-Martin et al. 1991; Casarégola et al. 1992). The highly charged segment contains the previously described arginine-rich RN A binding domain (ARRBD) (Cormack et al. 1993; Taraseviciene et al. 1995; McDowall and Cohen 1996). The AR-RBD is not necessary for EN DO or PAUN activity (M CDowall and Cohen 1996; Huang et al. 1998). In this study we have characterized protein-protein interactions within the degradosome. We show that the CTH of RN ase E contains binding sites for each of the three other major degradosomal components, PNPase, RhIB, and enolase. In addition, a polypeptide from the highly charged region of RN ase $E$, containing the RhIB binding site and the AR-RBD, strongly stimulates RhlB activity. A model for the reguIation of the RNA helicase activity within the degradosome is presented.

\section{Results}

The RNA helicase RhIB binds to the highly charged region of RNase $E$

We used Far Western blotting in our initial analysis of the protein interactions within the degradosome. Each of the degradosomal proteins were expressed by the $\mathrm{pET}$ system, separated by SDS-PAGE, transferred to a membrane, and renatured in situ. In an initial experiment using RN ase $\mathrm{E}$ as a probe, we detected an interaction with the RN A helicase RhIB, but not enolase or PN Pase (data not shown). To localize the RhIB binding site of $\mathrm{RN}$ ase $\mathrm{E}$, different polypepti des encompassing the entire RN ase E protein were tested. Figure 1A shows a Coomassie-stained SDS-polyacrylamide gel of E. coli extracts in which these polypeptides were lightly overexpressed by a limited induction of $<30 \mathrm{~min}$ (lanes 4-9). In Figure 1C, the blotted proteins were incubated with RhIB in solution, and the bound protein was detected by use of a rabbit anti-RhlB serum. As expected, the over-

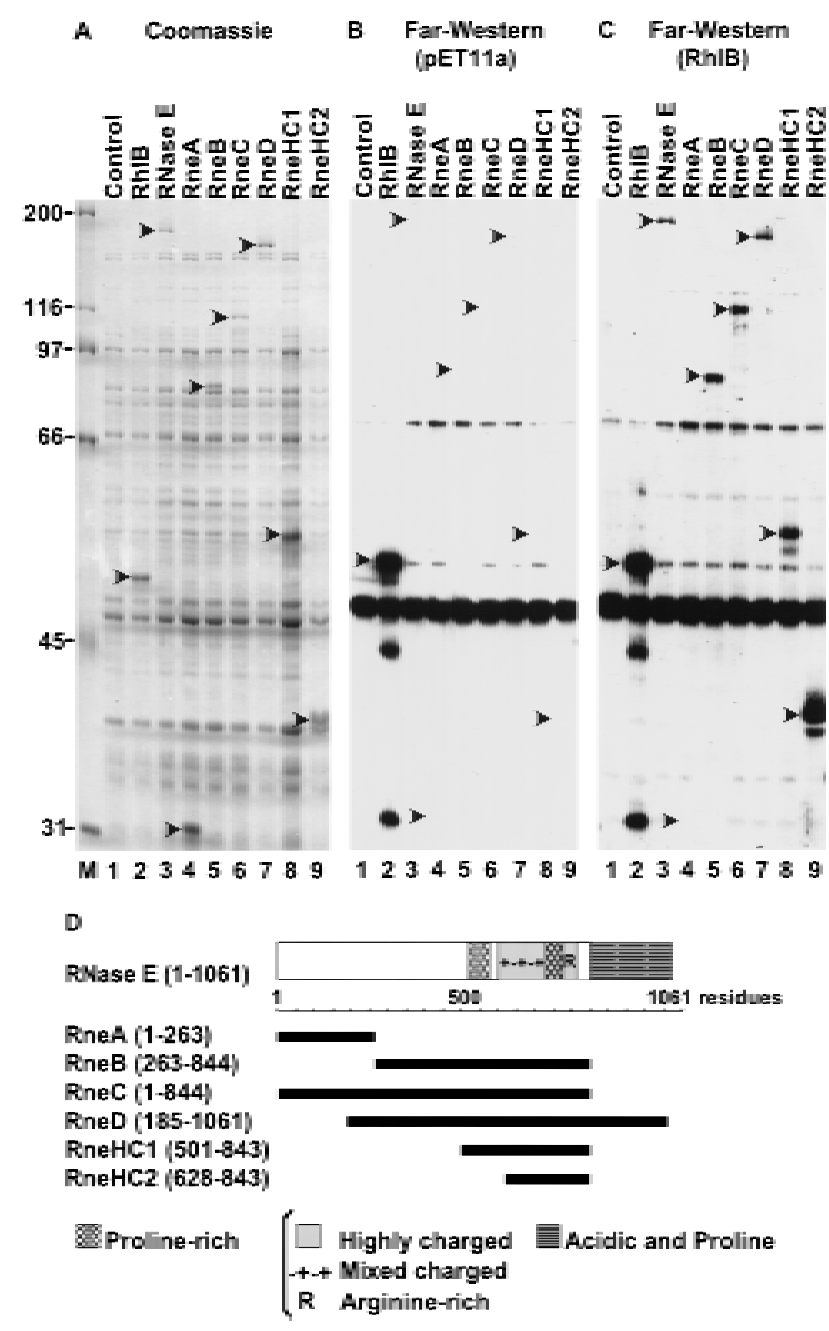

Figure 1. RhlB interacts with the highly charged region of RN ase E. (A) Crude extracts of BL21(DE3) containing the control vector pET1la (lane 1) or plasmids overexpressing RhlB, RN ase E, RneA, RneB, RneC, RneD, RneHC1, and RneHC2 (lanes 2-9) were analyzed on a 9\% SDS-polyacrylamide gel and stained with Coomassie blue. (C) For the Far Western analysis, the proteins were blotted to a membrane, incubated with RhIB in solution, and probed with an anti-RhIB antibody. The RhIB in solution was partially purified from E. coli with a pET derivative expressing RhIB. (B) A control in which the membrane was incubated with a mock preparation from $\mathrm{E}$. coli containing the pET 1la vector. In A, protein molecular masses $(k D)$ are marked at left. The position of the recombinant proteins was determined with Ponceau red and is indicated by arrowheads. (D) A schematic representation of the RN ase $\mathrm{E}$ polypeptides overexpressed by the $\mathrm{pET}$ system. The carboxy-terminal half can be roughly divided, by amino acid content, into a proline-rich segment (residues $524-568,33 \%$ proline), a highly charged (HC) domain (residues 600-820, 45\% charged), and an acidic terminal part rich in proline residues (845-1061, $20 \%$ acidic, $11 \%$ proline). The highly charged domain consists of three successive regions: a mixed charged region alternating arginine and acidic residues (600-738), a second proline-rich segment (739-778), and a short region mainly charged in arginine (789-820).

expressed RhIB transferred to the membrane is detected in lane 2. Lane 3 demonstrates that the RhIB probe in- 
teracts with full-length RN ase $\mathrm{E}$ on the membrane, confirming our initial reciprocal binding assay. Many proteins in lane 3 do not bind RhIB (cf. Fig.1, A and C) showing the specificity of the interaction under the conditions used. The interaction of RhIB with RneB, C, and D (lanes 5-7), but not RneA (lane 4), maps the binding site to the central region of RNase E (Fig. 1D). Two smaller polypeptides, RneHC 1 and RneHC2, also interact with RhlB (lanes 8,9), further limiting the binding site to the highly charged region of $\mathrm{RN}$ ase $\mathrm{E}$ from residues 628-843. The highly charged composition of these polypeptides is conferred by a large region containing both positively and negatively charged residues $(48 \%$ mixed charged), a proline-rich region ( $17 \%$ mixed charged) and a short arginine-rich stretch (43\% positively charged).

In Figure 1C, the RhIB protein used as a probe was partially purified (see Materials and Methods). This preparation was $>$ than $70 \%$ RhIB by Coomassie-stained SDS-PAGE (not shown). The control experiment in Figure 1B excludes any possibility that the anti-RhIB serum cross-reacts with RN ase E. The signal below RhIB (Fig. $1 B, C)$ is the result of a reaction of the anti-RhIB serum with another protein present in all the extracts. It is unlikely that the RN ase E-RhIB interaction detected here is caused by an RNA bridge. First, the bulk nucleic acid was removed by precipitation with polyethyleneimine (PEI) during the preparation of the RhIB probe. Second, the blots were incubated in the presence of pancreatic ribonuclease. Because the RhIB probe used in these experiments is not completely pure, we cannot exclude the possibility that the interaction with RN ase E is mediated by another protein. However, the yeast two-hybrid analysis presented next argues for a direct interaction between these two proteins.

Protein interactions detected by the yeast two-hybrid system

We also examined the interactions between the major proteins of the RNA degradosome using the yeast two- hybrid system that is based on a transcription activation assay (Golemis et al. 1994). RN ase E was divided into three regions: amino terminal (1-528), central (500-752), and carboxy terminal (734-1061). The entire protein was used for PN Pase, RhIB, and enolase. These proteins were fused to either the DNA-binding or the transcriptional activation domains. As shown in Table 1, all of the possible pair-wise combinations were tested. Six of the pairs activated transcription: (1) RN ase E amino-terminal region with itself; (2) RN ase E central region with itself; (3) RN ase E central region with RhIB; (4) RN ase E carboxyterminal region with RhIB; (5) RN ase E carboxy-terminal region with enolase; and (6) enolase with itself. For the three non-self interactions, each of the two possible pairwise combinations activated transcription. The interaction of the central (500-752) and carboxy-terminal (7341061 ) regions of $\mathrm{RN}$ ase $\mathrm{E}$ with $\mathrm{RhIB}$ confirms the results of the Far Western analysis and provides unambiguous support for a direct interaction between RN ase $E$ and $\mathrm{RhlB}$. The interaction with both regions suggests that important determinants for RhlB binding are located in the small overlap between the two constructs (734-752). This interpretation is supported by the in vivo analysis described bel ow. The association of enol ase with the carboxy-terminal region (734-1061) of RN ase E, but not with PNPase, was unexpected because enolase was shown previously to copurify with PN Pase (see Discussion). However, no interaction was detected between enolase and PN Pase by use of the two-hybrid system or by Far Western bl otting (data not shown), and the in vivo analysis described below also argues against a direct interaction between PN Pase and enolase. The enolase self reaction is consistent with a previous biochemical study showing that native enolase is a dimer (Spring and Wold 1971).

Construction of an E. coli strain for the conditional expression of RNase $\mathrm{E}$ mutants

We introduced an amber stop mutation at the first tyrosine codon of the rne gene in an E. coli strain carrying a

Table 1. Yeast two-hybrid analysis of interactions between the components of the RNA degradosome

\begin{tabular}{|c|c|c|c|c|c|c|}
\hline \multirow{3}{*}{$\begin{array}{l}\text { Activation } \\
\text { domain }\end{array}$} & \multicolumn{6}{|c|}{ DNA-binding domain } \\
\hline & \multicolumn{3}{|c|}{ RN ase $E$} & \multirow[b]{2}{*}{ RhlB } & \multirow[b]{2}{*}{ enolase } & \multirow[b]{2}{*}{ PN Pase } \\
\hline & amino-terminal & central & $\overline{\text { carboxy-terminal }}$ & & & \\
\hline \multicolumn{7}{|l|}{$\mathrm{RN}$ ase $\mathrm{E}$} \\
\hline amino-terminal & + & - & - & - & - & - \\
\hline central & - & + & - & + & - & - \\
\hline carboxy-terminal & - & - & - & + & + & - \\
\hline RhIB & - & + & + & - & - & - \\
\hline enolase & - & - & + & - & $x^{a}$ & - \\
\hline PN Pase & - & - & - & - & - & - \\
\hline
\end{tabular}

The regions of RN ase E correspond to 1-528, amino-terminal; 500-752, central; 734-1061, carboxy-terminal. The entire protein was used for RhIB, enolase, and PN Pase. All of the positive interactions (+) were $\mathrm{Lac}^{+}$and $\mathrm{Leu}^{+}$on the appropriate indicator plates. All the negative interactions $\left(\rightarrow\right.$ were $\mathrm{Lac}^{-}$and $\mathrm{Leu}^{-}$.

${ }^{\text {a}}$ For the enolase-enolase result $(x), \mathrm{Leu}^{+}$was detected but $\mathrm{LaC}^{+}$was only observed when the plasmid with the DNA binding domain was introduced after the plasmid with the activation domain. 
temperature-sensitive amber suppressor (Fig. 2A). The resulting strain, pBRN 1 , grew at $30^{\circ} \mathrm{C}$ but not at $42^{\circ} \mathrm{C}$, the nonpermissive temperature. This conditional growth was expected because RN ase $\mathrm{E}$ is an essential protein. Growth at $42^{\circ} \mathrm{C}$ was restored by complementation with a low-copy-number plasmid, pAM-rne, encoding the intact rne gene. A set of deletions in the carboxy-terminal regi on of RN ase $E$ was constructed by inverse PCR of the pAM-rne plasmid (Fig. 2B). These deletions were designed to remove the proline-rich, the highly charged, and the acidic regions of RN ase E. All the deletions except the largest, Rne $\Delta 15$, were able to complement the rne amber strain at $42^{\circ} \mathrm{C}$. This result confirms the report that E. coli strains with deletions of the CTH of RN ase E are viable (Kido et al. 1996). Figure 2C shows that the plasmid encoded RN ase E (lane 1) or the mutant proteins (lanes 2-6) are detected by Western blotting at the nonpermissive temperature (Rne $\Delta 16$ and Rne $\Delta 18$ not shown). As expected, the endogenous RN ase $E$ protein was not detected under these conditions.

Analysis of the composition of the degradosome by coimmunopurification

In an initial experiment with the pAM-rne plasmid expressing wild-type RN ase $E$ in the PBRN 1 strain, it was difficult to detect the coimmunopurification of RhIB with RN ase E. RhIB is probably poorly expressed because of the lack of a recognizable Shine-Dalgarno translation initiation sequence. The protein was not detected by two-dimensional gel electrophoresis of total proteins even when multiple copies of the gene are present (Kalman et al . 1991). We introduced into the PBRN 1 strain a medium-copy-number plasmid with rhlB under the control of the lac transcription and translation signals. The basal expression without IPTG induction was sufficient to permit easy detection of RhIB by Western blotting. All the results reported below were obtained in the presence of this plasmid.

In Figure 3, coimmunopurifications were performed by use of rabbit antibodies, against RNase $E(A, C)$ or PN Pase (B), which were cross-linked to protein A-Sepharose beads. The immunopurified complexes were released with SDS, separated by SDS-PAGE, and visualized by silver staining $(A, B)$. The identity of PNPase, RhIB, and enol ase was verified by Western blotting ( $A-C)$. Figure 3A, lane 3, shows that enolase, PNPase, and RhIB efficiently copurify with the full-length RNase E. For comparison, lane 1 shows a preparation of the RNA degradosome purified by ion exchange chromatography and glycerol gradient sedimentation (Py et al. 1996). Lane 2 is a control showing the background using beads with preimmune serum. All of the deletions in the CTH of RN ase $E$ affected the composition of the RNA degradosome except Rne $\Delta 12$ (lane 6) in which only the first proline-rich segment of RN ase $\mathrm{E}$ was del eted. The changes in composition range from subcomplexes missing PNPase (Rne $\Delta 10)$ or RhlB and enol ase (Rne $\Delta 13$ and Rne $\Delta 14$ ) to no degradosomal proteins associated with RNase $\mathrm{E}$ (Rnes11).

\section{The association of RhIB and enolase with RNase E}

With Rne $\Delta 10$ and Rne $\Delta 12$ (Fig. 3A, lanes 4,6), RhIB and enolase still copurify with RN ase $E$, showing that neither the acidic carboxyl terminus, nor the first prolinerich region, are essential for the presence of these proteins in the RNA degradosome. In contrast, they do not copurify with Rne $\Delta 11$, Rne $\Delta 13$, and Rne $\Delta 14$. These have in common a deletion (636-845) covering a large part of the highly charged region of RN ase E (see Fig. 2B). These in vivo results agree with experiments presented above showing that polypepti des from this regi on are sufficient to bind to RhIB. Although the copurification of enolase
A

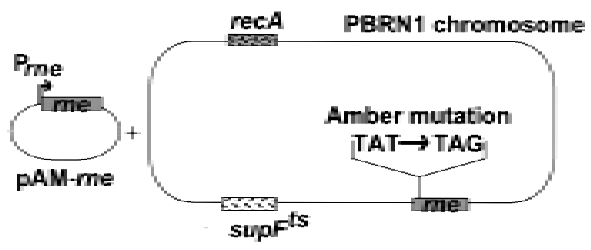

B

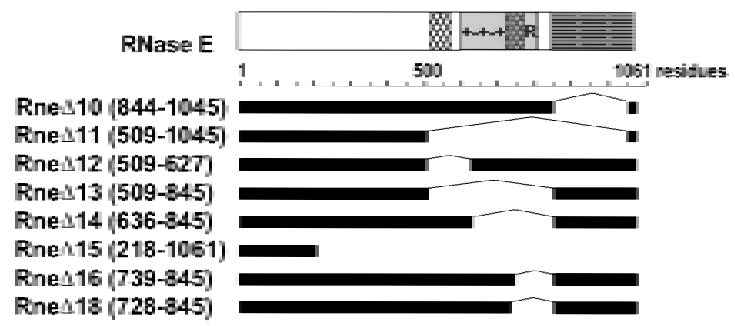

c

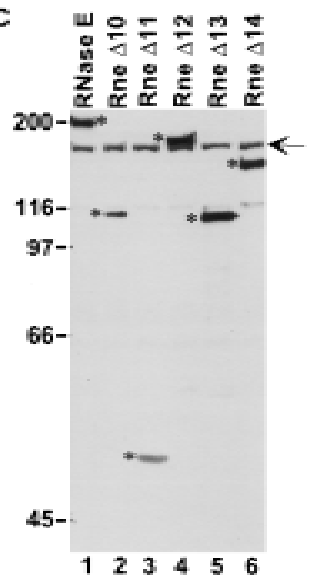

Figure 2. Construction of E. coli strains expressing various deletions in RN ase E. (A) A schematic representation of the experimental system. The PBRN 1 strain carries the rne gene with an amber mutation in its first tyrosine codon and the temperature-sensitive tRN A suppressor supF ${ }^{\text {ts }}$ that inserts tyrosine. At $30^{\circ} \mathrm{C}$, wild-type $\mathrm{RN}$ ase $\mathrm{E}$ protein is produced because of the suppression by supF ${ }^{\text {ts }}$. At $42^{\circ} \mathrm{C}$, a polypeptide containing only the first 25 amino acids of RN ase $E$ is produced and growth is supported by a plasmid encoding the wild-type RN ase E (pAM-rne). (B) The structure of the mutant proteins with the boundaries of the del etions noted in parentheses. The messages encoding these proteins, expressed from the rne promoter (Prne), contain the natural $5^{\prime}$ and $3^{\prime}$ UTR encoded by the rne gene. PBRN 1 containing PAM-rne and its derivatives was grown at $42^{\circ} \mathrm{C}$ to the stationary phase. Total cell extracts were analyzed by Western blotting with an anti-RN ase $\mathrm{E}$ antibody. (C) Expression of RN ase E and mutant peptides at $42^{\circ} \mathrm{C}$. The RN ase E polypeptides are marked by asterisks. The signal indicated by the arrow is the result of a cross-reaction of the antiserum with another protein present in all the extracts. 


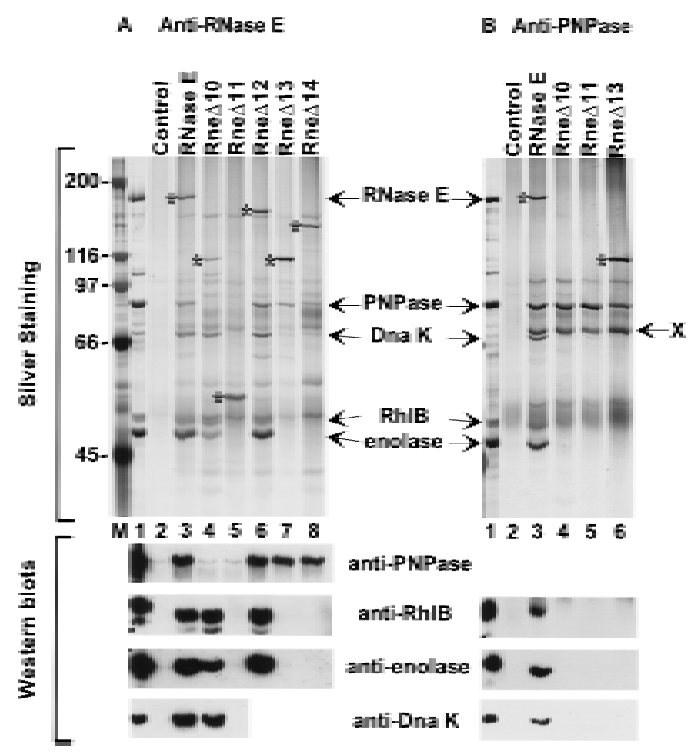

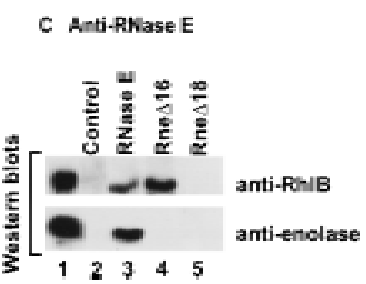

Figure 3. Analysis of the composition of the RNA degradosome. The PBRN 1 strain, containing PAM-rne or its derivatives and PAPTrhlB was grown at $42^{\circ} \mathrm{C}$ to stationary phase. Plasmid pAPT-rhIB is a p15A-derived plasmid expressing RhIB under the control of the Plac expression signals. Protein extracts were prepared as described in the Materials and Methods. Anti-RN ase $E$ antibody $(A, C)$ or anti-PN Pase antibody (B), cross-linked to protein A-Sepharose beads, was used to immunopurify the protein complexes. The composition of the immunopurified protein complexes was analyzed by SDS-PAGE and silver staining (top, A, B) or by Western blotting (bottom, A-C). (Lane 1) The RNA degradosome preparation from Py et al. (1996). (Lane 2) A control immunopurification using the preimmune serum for each antibody. The RN ase $E$ protein and its mutants are marked with asterisks. In B, X indicates an unrelated protein present in all the cell extracts that react with the anti-PN Pase antibody. The molecular masses of markers (lane M) are indicated at left (in kD). with the RN ase E mutants is the same as for RhlB, it is unlikely that the two proteins interact directly. First, using an antibody against enolase, RhlB does not copurify in the Rne $\Delta 11$ strain (data not shown). Furthermore, the two-hybrid analysis (see above) reveal ed a direct interaction between enolase and the carboxy-terminal part of RN ase E (734-1061). Taken together, these data argue for an enolase binding site between residues 734-845 of RNase E. Most of this region was deleted in Rne 16 (739-845) to test the interaction with enolase. As shown by the Western analysis in Fig. 3C, enolase does not copurify with Rnes16. However, RhIB still copurifies. This result shows clearly that the second half of the highly charged region of RNase E (residues 739-845) is important for the interaction with enolase.

In the yeast two-hybrid analysis, RhIB interacted with the central (500-752) and carboxy-terminal (734-1061) regions of $R N$ ase $E$ (Table 1 ) suggesting that the RhIB binding site spans the overlap (734-752). When most of this region is deleted in Rne $\Delta 16$ (739-845), RhIB still efficiently copurifies with RNase E (Fig. 3C, lane 4) indicating that residues $739-752$ are not critical for RhIB binding. However, with the slightly larger deletion, Rne $\Delta 18$ (728-845), the interaction with RhIB was disrupted (lane 5), showing that residues necessary for the binding are located in the small segment, from 734 to 738 (SVAEE), in the highly charged region of RN ase E.

\section{The association of PNPase with RNase $E$}

PN Pase copurifies with all of the RN ase $E$ deletions except Rne $\Delta 10$ and Rne $\Delta 11$ (Fig. 3A, lanes 4,5). The loss of interaction with PN Pase in the Rne 111 strain confirms the report that the CTH of RN ase E is required for the interaction with PN Pase (Kido et al. 1996). The Rne 10 strain permits a more precise mapping of the interaction site to the acidic segment in the last 217 residues of $\mathrm{RN}$ ase $\mathrm{E}$. This result was confirmed by immunopurification of PN Pase (Fig. 3B). Full-length RN ase E, enolase, and RhIB copurified with PN Pase as expected (lane 3). The Rne $\Delta 10$ and Rne $\Delta 11$ polypeptides did not copurify with PN Pase (lanes 4,5). Enol ase and RhIB were also not detected. Moreover, Rnes13 (lane 6), which still contains the last 217 amino acids of RN ase E, copurified with PN Pase, but not enolase and RhIB. Thus, a direct interaction between PN Pase and enol ase or RhIB cannot be detected, indicating that their association in the degradosome is mediated through their independent interaction with the CTH of RNase E.

\section{The association of DnaK with RNase E}

Additional minor polypepti des were shown previously to copurify with the RNA degradosome (Carpousis et al. 1994; Py et al. 1996). One of these components was identified as DnaK in the degradosome purified by use of a FLA G-tagged RN ase $E$ and in our degradosome preparations (M iczack et al. 1996; Blum et al. 1997). As shown in Figure $3(A, B)$, DnaK was detected by silver staining and Western analysis in our purified degradosome preparation (lane 1) and also by immunopurification of fulllength RN ase E (lane 3). DnaK efficiently copurified with Rne $\Delta 10$, a deletion of the acidic carboxyl terminus of $\mathrm{RN}$ ase $\mathrm{E}$ which disrupts the association with PN Pase (Fig. 3A, lane 4), yet did not coimmunopurify with PNPase in the Rne $\Delta 10$ background (Fig. 3B, Iane 4). These results demonstrate that DnaK does not interact di rectly with PN Pase. DnaK did not copurify with Rne $\Delta 11$ (Fig. $3 A$, Iane 5), implicating the central part of RN ase $E$ in the association of DnaK with the degradosome. Whether DnaK interacts directly with RN ase $\mathrm{E}$, or through RhIB and enolase, remains to be clarified.

The interaction with the highly charged region of RNase E stimulates RhlB activity

Our results show that RhIB and RNase E physically interact. Because we found previously that RhlB by itself 
Structural organization of the RNA degradosome

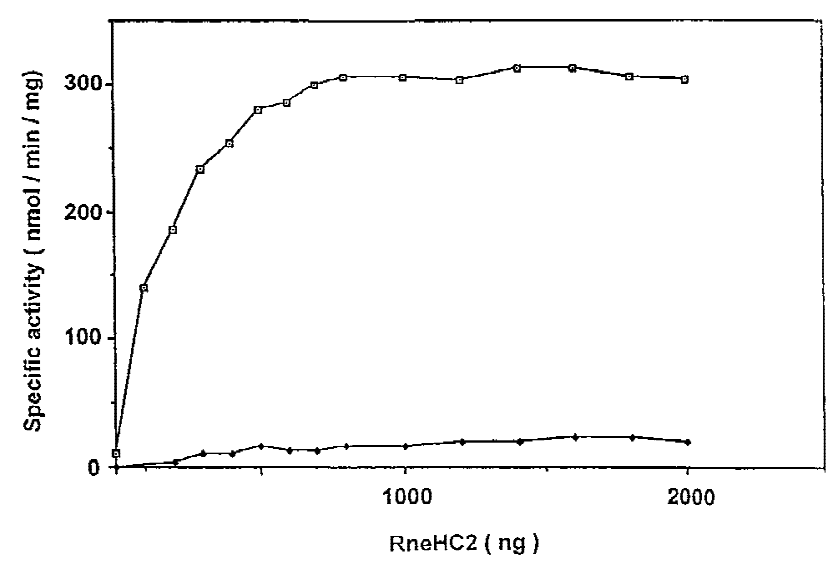

Figure 4. The RneHC2 polypeptide stimulates RhIB ATPase activity. The specific ATPase activity of wild-type $(\square)$ and mutant $(\diamond)$ RhIB protein was determined in the presence of increasing concentrations of the RneHC2 polypeptide. The values are the average of duplicate assays. The reactions, containing $1 \mu \mathrm{g}$ of RhIB and 0-2 $\mu \mathrm{g}$ of the RneHC2 polypeptide, were as described (Py et al. 1996), except that the yeast RN A was increased to $200 \mu \mathrm{g} / \mathrm{ml}$. Less than $15 \%$ of the ATP was converted to ADP and $\mathrm{Pi}$ under the conditions of maximal activity. RhlB* carries the E166K point mutation in the DEAD motif (DEAD $\rightarrow$ DKAD). RhIB, RhlB*, and RneHC2 were partially purified from cells overexpressing these proteins. Each protein was judged to be at least $70 \%$ pure by SDS-PAGE. Protein concentrations were determined by Lowry assay using a BSA standard.

had no detectable ATPase activity (Py et al. 1996), we tested the effect of RNase $E$ binding on RhIB activity. Preliminary experiments with the full-length RN ase $E$ and the RneD polypeptide suggested that these proteins can stimulate RhIB activity. Figure 4 shows an assay of RhlB ATPase activity in the presence of increasing amounts of RneHC2 [(HC) highly charged], the smallest RN ase $E$ polypepti de shown to interact with RhIB by Far Western analysis. As a control, we used a mutant, RhIB*, in which the DEAD motif was changed to DKAD. A mutation in the same position in rabbit elF4A, another DEAD-box RN A helicase, is known to abolish ATPase activity (Pause and Sonenberg 1992). As shown in Figure 4, no significant activity was detected for the RhIB mutant in the presence of saturating amounts of RneHC2, even though RhIB* binds to RneHC2 as reveal ed by Far Western blotting (data not shown). These results indicate that RneHC2 is an autonomous protein domain sufficient to mediate both the interaction with the RNA helicase and the stimulation of its ATPase activity.

In Figure 4, the specific activity for wild-type RhIB is $300 \mathrm{U} / \mathrm{mg}$ with saturating RneHC2. This value is in reasonable agreement with the previous measurement of $190 \mathrm{U} / \mathrm{mg}$ in the RNA degradosome (Py et al. 1996). Without RneHC2 activation, the specific activity is $<20$ $\mathrm{U} / \mathrm{mg}$ showing at least a 15 -fold stimulation. From Figure 4 , we estimate that the activity saturates at $\sim 0.6 \mu \mathrm{g}$ of RneHC2 in a reaction containing $1 \mu \mathrm{g}$ of RhIB. Correcting for their molecular weights, this corresponds to one molecule of RneHC2 per molecule of RhIB.

\section{Discussion}

The carboxy-terminal half of RNase $E$ organizes the degradosomal protein interactions

The protein interactions between the components of the RNA degradosome were investigated by three complementary techniques: Far Western bl otting, the yeast twohybrid assay, and coimmunopurification. The Far Western and two-hybrid analyses were particularly useful in identifying specific regions of interaction within RN ase $\mathrm{E}$, whereas the coimmunopurification experiments provided direct information about the organization of the degradosome in the bacterial cell. The main conclusion of the combined approaches is that the CTH of RN ase E constitutes the structural core of the degradosome around which RhIB, enolase, and PN Pase assemble (Fig. $5 A$ ). Our results clearly demonstrate that the CTH of RN ase E contains distinct binding sites for each of these proteins. In addition, we did not detect any direct interactions between RhlB, enolase, and PN Pase. By deleting their binding sites in the CTH of RN ase E, it was possible to generate subcompl exes of the degradosome containing three components (RNase E-RhlB-enolase and RN ase E-RhIB-PNPase) or two components (RNase E-

A

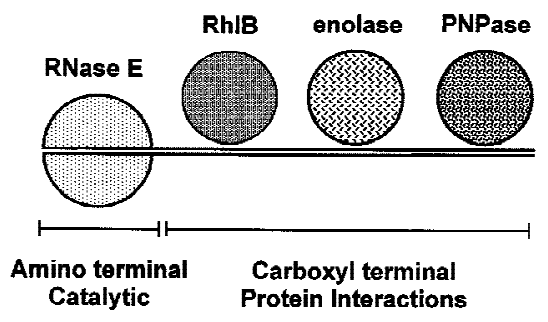

B

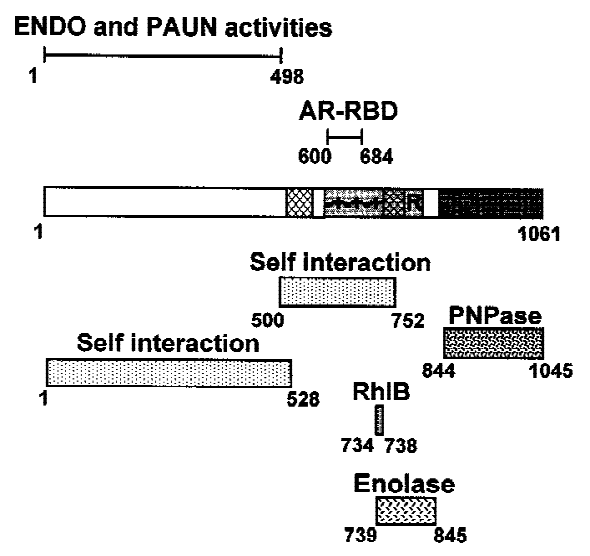

Figure 5. Organization of the protein interactions within the RN A degradosome. (A) Cartoon of the E. coli RN A degradosome illustrating the central role of the CTH of RN ase E in the protein interactions. The actual stoichiometry and structure of the components within the degradosome are not certain. It seems reasonable to suppose that $\mathrm{RN}$ ase $\mathrm{E}$ is dimeric although a trimeric or higher order structure is possible (see Discussion). (B) Summary diagram illustrating the known activities and binding regions in $\mathrm{RN}$ ase $\mathrm{E}$. 
PN Pase and RN ase E-RhIB). This shows that the individual deletions do not significantly affect the other binding sites, revealing a multidomain structural organization of the CTH of RN ase $E$.

Only the amino-terminal half of RN ase $E$, known to contain the ENDO activity, is essential for cell viability (Jain and Belasco 1995; Taraseviciene et al. 1995). N evertheless, we believe that the integrity of the degradosome is important for normal mRNA turnover. Several E. coli mutants expressing an RN ase $E$ that is missing the CTH of the protein were obtained in a selection for extragenic suppressors of a temperature-sensitive mukB allele (Kido et al. 1996). The suppressor strains overexpress the defective MukB protein twofold, apparently caused by the slower turnover of the mukB message. In our strains, the deletion of the CTH of RN ase E (Rne $\Delta 11$ ) leads to a threefold slower degradation of RNA1 (N.F. Vanzo and A.J. Carpousis, unpubl.), an antisense RNA whose degradati on depends on both RN ase E and PN Pase (Cohen 1995; Xu and Cohen 1995). Whether these effects are caused by the disruption of the RNA degradosome or defective RN ase E activity remains to be clarified.

\section{Protein interactions in the RNA degradosome}

Figure 5B summarizes our current understanding of the structural and functional features of RN ase $E$. The regions of RN ase $\mathrm{E}$ identified here, involved in the interaction with itself or the other components of the degradosome, are indicated in the lower part of Figure 5B. The best localized site is that of RhIB. An interaction with the central region of RN ase $\mathrm{E}$ was detected by Far Western analysis and a core site from 734 to 738 was determined on the basis of two-hybrid and coimmunopurification results. This stretch of five residues (SVAEE) lies at the carboxy-terminal end of the mixed charge region in the highly charged domain of RN ase E. Our in vivo results indicate that the core site is essential for RhIB association with the degradosome, but flanking residues could al so be important for the structure of this site. The enol ase binding site (739-845), defined by a combination of two-hybrid and coimmunopurification experiments, includes the proline and arginine-rich segments of the highly charged region. The in vivo anal ysis of the degradosome has permitted us to restrict the PN Pase binding site to residues 844-1045 in the acidic carboxy-terminal part of RN ase E. For enolase and PN Pase, the actual binding sites could be smaller than defined here and further experiments will be required to identify the critical residues for these interactions. We were not able to detect the RNase E-PN Pase interaction by Far Western blotting or two-hybrid analysis. Highly purified, enzymatically active PN Pase is a trimer of the 78-kD chains, forming a large 234-kD native protein (Littauer and Soreq 1982). This native trimeric state could be critical for the interaction with RN ase E. In contrast to the experiments in the bacterial cell where PN Pase can properly fold and assemble, its misfol ding on a membrane or in yeast could account for the failure to detect an interaction. Our results highlight the importance of using a variety of techniques to identify the proteins interactions within a complex such as the RN A degradosome.

$\mathrm{N}$ one of these methods have detected a direct interaction between PN Pase and enolase. Because of the identification of the $\beta$-subunit of PN Pase as enolase (Py et al. 1996), this result is surprising. The $\beta$-subunit copurifies with PN Pase under certain conditions, but it is not essential for phosphorylase activity (Portier 1975; Soreq and Littauer 1977). Our in vivo experiments clearly show that enol ase fails to copurify with PN Pase in the absence of RNase $E$, demonstrating that RNase $E$ serves as a bridge between these two proteins. It is known that RN ase E is very sensitive to proteolysis during purification (Carpousis et al. 1994). We believe that the copurification of enolase with PN Pase reported previously could be mediated by degradation products from the $\mathrm{CTH}$ of RN ase E. Because the enolase and PN Pase binding sites are next to each other in the CTH of RN ase E, a rel atively small RN ase E polypeptide of 100-300 amino acids could bind both proteins.

The self interactions of the amino and central regions of RN ase E detected in our two-hybrid analysis is the first direct evidence for its capacity to oligomerize. A previous analysis of the degradation of the $\$ 20$ ribosomal protein message suggested that native RN ase E is composed of at least two active subunits (Mackie et al. 1997). Many enzymes are only active in their multimeric native state and the oligomerization of the amino-terminal half of RN ase E could be necessary for the ENDO or PAUN activities. The self interaction of the central re gion suggests that the $\mathrm{CTH}$ of RNase $\mathrm{E}$ may also be oligomeric. Whether this oligomerization is important for the protein interactions remains to be determined. The quaternary structure of RNase $E$ in the complex is unsure as a result of the significant heterogeneity in the degradosome preparations. Carpousis et al. (1994) suggested that RNase $\mathrm{E}$ was dimeric on the basis of the stoichiometry of the degradosomal components in an immunoprecipitate, and an estimation of the molecular weight of the complex by sedimentation.

\section{Activation of the RNA helicase RhIB by the highly charged region of $\mathrm{RN}$ ase $\mathrm{E}$}

On the basis of a sequence analysis of its gene, RhIB was initially identified as a member of the DEAD-box family of ATP-dependent RNA helicases, known to unwind double-stranded regions (Kal man et al . 1991). Consistent with this identification, in vitro experiments showed that RhIB in the degradosome facilitates the PNPasemediated degradation of structured RN A in an ATP-dependent reaction (Py et al. 1996). In addition, the purified RNA degradosome has an RNA-dependent ATPase, a characteristic activity of the DEAD-box proteins. N evertheless, overexpressed and partially purified RhIB does not by itself have a detectable ATPase activity. The work described here shows that RhIB interacts with the highly charged region of $\mathrm{RN}$ ase $\mathrm{E}$ and that this interaction stimulates its activity at least 15-fold. The RneHC2 polypeptide, containing the core RhIB binding site, can 
fully activate RhIB to a specific activity comparable with that previously measured in the RN A degradosome. This stimulation saturates at a stoi chi ometry of one mol ecule of RneHC2 per molecule of RhlB.

$\mathrm{RhIB}$ is the second example of a DEAD-box helicase stimulated by a protein partner. The eukaryotic translation factor el F4B stimulates the RN A unwinding activity of elF4A, the prototype of the DEAD-box family (Rozen et al. 1990; Pause et al. 1992). Members of this family share a core region of $\sim 300$ amino acids containing eight highly conserved motifs (Schmid and Linder 1992). It has been proposed that this core domain is insufficient for RNA helicase activity and that an additional RN A-binding site is required (Gibson and Thompson 1994). This could be provided by a domain adjacent to the core or by a protein partner. el F4B has been suggested to supply the additional RNA-binding domain for the activation of elF4A (M il burn et al. 1990; Pause et al. 1992). RhlB contains an arginine-rich stretch at the carboxyl terminus that is predicted by primary sequence analysis (Gascuel and Golmard 1988) to be in a random coil conformation. The interaction with RneHC2 could fold this region into a functional RNA-binding site, activating the helicase. The other possibility is that RneHC2, which contains most of the AR-RBD, supplies the additional RN A-binding site. This would directly implicate the AR-RBD, which is not required for ENDO or PAUN activity, in the regulation and specificity of RhlB. Recent experiments with purified RhIB and RneHC2 demonstrate the unwinding of short RNA duplexes in an ATP-dependent reaction (N.F. Vanzo and A.J. Carpousis, unpubl.). Thus, it should be possible to directly examine the mechanism of stimulation of the RhIB helicase activity by the highly charged region of RN ase $\mathrm{E}$.

There are now many examples of enzymes, acting in the same biol ogical process, that are associated in a complex (see Alberts 1998 and references therein). Recently, degradosomelike complexes have also been described in eukaryotes (see introductory section). It is evident that these sophisticated protein machines offer the possibility to regulate and coordinate the activities of the individual components. The activation of the RNA helicase RhIB by RN ase E, demonstrated here, is one example of this type of control.

\section{Materials and methods}

\section{Bacterial strains and plasmids}

The XA 103 strain [nalA rif $\operatorname{argE}(\mathrm{am})$ supF metB thi ara $\Delta$ (lacpro)] and the supF ${ }^{\text {ts }}$ strain PB4144 (KH5402; Kimura et al. 1979) were kindly provided by J. Miller (UCLA) and D. Lane (CNRS), respectively. AC23 (ams zce-726::Tn10), a derivative of MC1061, is isogenic with the previously described $\mathrm{CH} 1828$ strain (M udd et al. 1990). The wild-type rne gene of XA 103 was substituted by the ams allele by P1 transduction using AC23 strain as donor. A streptomycin-resistant derivative of XA103 ams was isolated by plating on $200 \mu \mathrm{g} / \mathrm{ml}$ of the antibiotic. The resulting strain was named $X A 103^{a}$.

The E. coli strain used for most of DNA manipulations in this study was $\mathrm{DH} 5 \alpha \mathrm{F}^{\prime}\left(\mathrm{F}^{\prime} / \mathrm{endA} 1 \mathrm{hsdR} 17\left(\mathrm{r}_{\mathrm{k}}-\mathrm{m}_{\mathrm{k}}{ }^{+}\right)\right.$supE44 thi-1 recA1 gyrA (Nal') relA1 $\Delta$ (lacZYA-argF)U169 deoR ( $\phi 80$ dlac $\Delta($ lacZ)M15). The BL21(DE3) strain (N ovagen) was used for protein overexpression. To overexpress PN Pase, the E. coli pnp coding region was amplified by PCR with pfu DNA polymerase (Stratagene) by use of primers pnpl and pnp2 (T able 3 , below). This PCR product was cloned into pUC18 and then into pET 1la, as described for the pcnB gene by Raynal et al. (1996). The pET 11a derivatives for the overexpression of enolase and RhIB were constructed previously (Py et al. 1996) by the same procedure.

Vectors encoding polypeptides derived from the rne gene

The plasmid $\mathrm{pET}$-rne overexpressing full-length RN ase E protein was constructed as follows. First, a 3.5-kb A pol-A pol chromosomal fragment containing the entire rne gene was cloned in the EcoRI site of the PET 1la vector. A clone having the rne gene in the same orientation as the T7 RNA polymerase transcription gave the pET-rnel plasmid. Second, a PCR-generated fragment encoding residues 1-217 of the RNase E protein was cloned into the Smal site of pU C 18 vector to give the pUC-rnel plasmid. The primers for PCR were rne541 and rnel192 ( $T$ able 3 , below). After sequencing, the $\mathrm{N} \mathrm{del-HindlII} \mathrm{rne} \mathrm{fragment} \mathrm{was}$ excised and ligated to the pET-rnel plasmid digested by the same enzymes to make the pET-rne plasmid. Other constructions are as shown in Table 2 and the primers for PCR are listed in Table 3. Polypeptides RneB, RneD, RneH C1, and RneH C 2 are translational fusions with the first 13 residues of bacteriophage T 7 gene 10 protein. To construct the $p E T-r n e D$ plasmid, a HindIII-A pol rne fragment was excised from pET-rne plasmid and subcloned into pGEM -7Zf vector (Promega) di gested by HindllI-EcoRI to give pGEM-rneD plasmid. This plasmid was digested by BamHI and Apol, liberating BamHI-BamHI and BamHIA pol rne fragments. Both were ligated with the $\mathrm{pET} 11 \mathrm{~b}$ vector digested by BamHI and EcoRI. A clone with the correct orientation of the BamHI fragment was chosen on the basis of restriction analysis.

\section{Protein overexpression and preparation of extracts}

Crude protein extracts for the blots in the Far Western analysis were prepared as follows. A fresh overnight colony of BL21(DE3) containing the appropriate plasmid was grown at $37^{\circ} \mathrm{C}$ in LBampicillin to $O D_{600 \mathrm{~nm}}=0.4$. The culture was then shifted to $30^{\circ} \mathrm{C}$ to optimize solubilization of overexpressed proteins and induced from 20-30 min with $1 \mathrm{~mm}$ IPTG. Lysates were prepared as in Carpousis et al. (1994) with some modifications. Briefly, the cultures were concentrated 25 -fold and suspended in the lysosyme-EDTA buffer, and the cells were broken with a freeze-thaw step. The DN ase-Triton buffer was added, and the suspension was incubated for $30 \mathrm{~min}$ with agitation and then adjusted to $1 \mathrm{M} \mathrm{NH}_{4} \mathrm{Cl}$.

To obtain partially purified proteins as probes for the Far Western analysis, and for the RhIB AT Pase assay, crude extracts were prepared as described above except that the induction time was for $2 \mathrm{hr}$. The extracts were clarified by centrifugation (15 min, 10,000g), the supernatants were collected and PEI was added slowly with gentle agitation to a final concentration of $0.2 \%$ (Gegenheimer 1990). The precipitated nucleic acid was removed by centrifugation ( $15 \mathrm{~min}, 10,000 \mathrm{~g}$ ), the PEI was removed by precipitating proteins with $60 \%$ ammonium sulfate, and the pellets were suspended in buffer A containing $200 \mathrm{~mm}$ $\mathrm{NaCl}$ (Carpousis et al. 1994).

Western and Far Western analysis

Protein gels and Western blotting were performed as described 
Table 2. Plasmids expressing RNase E polypeptides

\begin{tabular}{llc}
\hline Vector (restriction sites) & \multicolumn{1}{c}{ rne insert } & Plasmid (residues encoded) \\
\hline pET 1la (N del-EcoRI) & N del-A pol fragment & pET-rne (1-1061) \\
pET 1la (N del-BamHI) & N del-BstYI from pET-rne & pET-rneA (1-263) \\
pET 1lc (BamHI) & BstYI-BamHI from pET-rne & pET-rneB (263-844) \\
pET 1la (Ndel-BamHI) & Ndel-BamHI from pET-rne & pET-rneC (1-844) \\
pET 11b (BamHI-EcoRI) & BamHI-A pol from pGEM-rneD & pET-rneD (185-1061) \\
pET 11c (BamHI filled) & PCR-generated fragment ${ }^{a}$ & pET-rneHC1 (501-843) \\
pET 1lc (BamHI filled) & PCR-generated fragment & pET-rneHC2 (628-843) \\
\hline
\end{tabular}

aprimers rne2041 and rne3069.

bPrimers rne2422 and rne3069.

in Raynal et al. (1996) except that gels were electroblotted with a carbonate transfer buffer (Dunn 1986) for $12 \mathrm{hr}$ at $60 \mathrm{~mA}$. Polyclonal antibodies against the purified components of the RNA degradosome were raised in rabbits (Eurogentec). Polyclonal rabbit antiserum against E. coli DnaK was a gift from Bernd Bukau (University of Frei burg, Germany). For Far Western analysis, the blots were placed in TEN 50 buffer (Cormack et al. 1993) and stored at $4^{\circ} \mathrm{C}$ for a minimum of 5 days to permit in situ renaturation of proteins. Filters were blocked for $1 \mathrm{hr}$ in HHB (HEPES-hybridization buffer; $20 \mathrm{mM} \mathrm{HEPES} \mathrm{at} \mathrm{pH} \mathrm{7.7,} 75$ $\mathrm{mm} \mathrm{K} \overline{\mathrm{Cl}}, 0.1 \overline{\mathrm{mm}}$ EDTA, $2 . \overline{\mathrm{mm} \mathrm{M} \mathrm{MCl}}, 1 \mathrm{~mm}$ DTT, $0.05 \%$ Triton) containing 5\% nonfat milk. Membranes were then incubated overnight at $4^{\circ} \mathrm{C}$ in $\mathrm{HHB}$ supplemented with $1 \%$ nonfat milk, RN ase A $(0.2 \mu \mathrm{g} / \mathrm{ml}$ final), and the appropriate partially purified protein. Filters were washed three times for $10 \mathrm{~min}$ with $\mathrm{HBB}$ supplemented with $1 \%$ nonfat milk and submitted to Western analysis.

Yeast plasmids

The plasmid vectors used for yeast two-hybrid analysis, pEG202, pJG4-5, pJK101, pRFHM-1, pSH17-4, and pSH 18-34, were provided by Roger Brent and are described in Golemis et al. (1994). pBluescript K+ was from Stratagene. Genes encoding components of the degradosome were amplified with Vent polymerase ( $\mathrm{N}$ ew England Biolabs) and inserted into either pEG202

Table 3. Primers used in this study

\begin{tabular}{|c|c|}
\hline Name & Sequence (from $5^{\prime}$ to $\left.3^{\prime}\right)^{a}$ \\
\hline rne215 & ggatccTACGGAATAACCCATTTTGCCCGAC \\
\hline rne541 & atATGAAAAGAATGTTAATCAACGCAACTCAGC \\
\hline rne627 & GATATCCAGGTCCTACAGACGCTGCCC \\
\hline rnel192 & ATGCGCGAACGATTACGTTGCTCT \\
\hline rne2041 & ATGCTGCCGAAGCTGCATGAAGAA \\
\hline rne2064 & TTCTTCATGCAGCTTCGGCAGCATG \\
\hline rne2422 & GAACGTACTGAAGGCAGCGATAATC \\
\hline rne2445 & ATTATCGCTGCCTTCAGTACGTTC \\
\hline rne2721 & CTGATTGAGCTGACGCTGTTTACGACGCGGC \\
\hline rne2754 & TTCTTCGGCTACGCTTTGCTCGTAACGC \\
\hline rne3069 & CCAGACTTTGCCAGAGGCCAGTTC \\
\hline rne3076 & TATCCAATTGTACGTCCGCAAGATGTAC \\
\hline rne3676 & GCAACACGTCATGCCTCTGCCG \\
\hline rneYSL1 & GAGTAAgaattcATGAAAAGAATGTTAATC \\
\hline rneYSL2 & GCGCGctcgagTTACGCAGGTTGTTCCGGACGCTTAC \\
\hline rneYSL3 & CCAACC gaattcTACATGCTGCCGAAGCTG \\
\hline rneYSL4 & TTCCTGctcgagTTATTCGGCAGCGACAGTTTC \\
\hline rneYSL5 & CGTTACgaattcAGCGTAGCCGAAGAAGCG \\
\hline rneYSL6 & ACTTTGctcgagTTATTAtTCcACAGGTTG \\
\hline pnpl & atATGCTTAATCCGATCGTTCGTAAATTCC \\
\hline pnp2 & TTACTCGCCCTGTTCAGCAGCC \\
\hline pnpYSL1 & GGGCG gaattcATGCTTAATCCGATCGTT \\
\hline pnpYSL2 & GGGGGctcgagTTACTCGCCCTGTTCAGC \\
\hline rhlB607K & ATTCAGGTGGTGGTACTGGACaAAGCCGATCGCA \\
\hline rhlB1282R & ATTTGCTTACCGGAATTGAGT \\
\hline rhIBYSL1 & GGGCGgaattcATGAGCAAAACACATTTAACAG \\
\hline rhIBYSL2 & GGGGGctcgagTTAACCTGAACGACGACGATTACGCGG \\
\hline enoYSL1 & CTTGAGGggatccTAATGTCCAAAATCGTAAAAATC \\
\hline enoYSL2 & CTAGTT ctcgagT CAGATAAAGTCAGTCTTATG \\
\hline enoYSL3 & CTTGAGGAActcgagATGTCCAAAATCGTAAAAATC \\
\hline enoYSL4 & GCTAGTTctcgagTCAGATAAAGTCAGTCTTATG \\
\hline
\end{tabular}

aThe lowercase letters, showing the substitutions introduced to manufacture restriction sites, prevent secondary structure formation within the primer or create mutations. 
(to generate bait plasmids; pB series) or into pJG4-5 (to generate activation plasmids; $\mathrm{pA}$ series). Restriction sites were added to aid cloning. The $\mathrm{pB}$ series of plasmids result in a fusion between the protein of interest and the DNA-binding protein LexA. The pA series of plasmids result in a fusion between the protein of interest and an acidic domain (acid blob), which functions as a portable transcriptional activation motif.

Plasmid pBP1, containing the E. coli pnp gene, was constructed by PCR with primers pnpYSL1 and pnpYSL2, cloning the EcoRI- and Xhol-digested PCR product into pEG202 digested with the same enzymes. Plasmid pBB, which expresses RhIB, was constructed similarly with primers rhIBYSL 1 and rhlBYSL2. For pBEN, which expresses residues 1-528 of the aminoterminal domain of RN ase E, primers rneYSL1 and rneYSL2 were used. For pBECN, which expresses the central domain of RN ase E (residues 500-752), primers rneYSL 3 and rneYSL4 were used. For pBEC, which expresses the carboxy-terminal domain of RN ase E (residues 734-1061), primers rneYSL5 and rneYSL6 were used. These fragments were all cloned into pEG202 digested with EcoRI and Xhol. Plasmid pBEN O, which expresses the enolase gene, was amplified with primers enoYSL1 and enoYSL2 and cloned into pEG202 cut with BamHI and Xhol.

Plasmids pAP expressing PNPase, pAB expressing RhIB, pAEN expressing RN ase E amino-terminal domain, pAECN expressing RN ase $E$ central domain, and pAEC expressing RN ase $\mathrm{E}$ carboxy-terminal domain used the same amplified genes as the $p B$ vectors, but cloned into pJ G 4-5 cut with EcoRI and Xhol. Plasmid pAENO, expressing enolase, was made with primers enoYSL3 and enoYSL4, then cloned into pJG4-5 cut with Xhol. Some of the inserts were blunt-end ligated into pBluescript $\mathrm{K}+$ before being subcloned into their appropriate yeast two-hybrid vectors.

\section{Yeast two-hybrid analysis}

The two-hybrid method used here is based on the LexA-B42 acid bl ob system (Gyuris et al. 1993). The two reporter genes are LexAop-LEU 2 and LexAop-LacZ. EGY 48 (ura3, trp1, his3, lexA operator-LEU 2) was the yeast strain used throughout. Cells were grown in YPD or complete minimal (CM) dropout media as described by Golemis et al. (1994) except for X-gal plates that contained $0.07 \mathrm{M}$ of potassium phosphate ( $\mathrm{pH} 7.0)$, and 0.04 $\mu \mathrm{g} / \mathrm{ml} \mathrm{X-gal} \mathrm{(Sambrook} \mathrm{et} \mathrm{al.} \mathrm{1989).} \mathrm{Y} \mathrm{east} \mathrm{transformations} \mathrm{were}$ performed according to Gietz et al. (1992), and nutritional selection was maintained throughout.

EGY 48 was cotransformed with pSH 18-34 and the pB series. Plasmids from the pA series were then introduced into these transformed yeast and selected at $30^{\circ} \mathrm{C}$ on solid $\mathrm{CM}$-glucose ( $-U$ ra, - His, and - Trp). Six colonies from each transformation were streaked on CM-glucose ( $-U \mathrm{ra}$, $-\mathrm{His}$, and $-\mathrm{Trp})$, re streaked on the test plates, and observed for 3 days. The interaction trap testing and controls (e.g., checking that the $\mathrm{pB}$ series did not autoactivate the reporter genes and were able to repress the LexA operators) were as described by Golemis et al. (1994), except that the tests were carried out on plates instead of using the liquid $\beta$-galactosidase filter assay. A positive interaction was interpreted as those transformants that turned blue on CMgal actose-X-gal ( $-\mathrm{U}$ ra, $-\mathrm{His}$, and -Trp) and were able to grow on CM-galactose (-Ura, -His, and -Trp) without leucine.

\section{Construction of the PBRN 1 strain}

Introduction of the amber mutation was carried out in two steps. First, we cloned into the thermosensible pSC101-based vector pFC 13 (Cornet et al. 1994) the rne gene in which the first tyrosine codon (TAT), encoding amino acid 25 of RN ase E, was changed to an amber stop codon (TAG). Then, we used this plasmid to introduce the tyr25am mutation on the chromosome by homologous recombination.

Introduction of the tyr25am mutation in the rne gene and cloning into the pFC13 vector was carried out in several steps. First, a BamHI-EcoRV rne fragment containing the amber mutation was constructed by PCR-directed mutagenesis. The downstream mutagenic primer was rne627 (lowercase c creates the amber mutation TAG, Table 3). The upstream primer was rne215. The former hybridizes near the RN ase $\mathrm{E}$ processing site in the $5^{\prime}$ UTR rne gene and creates a BamHI site (lowercase letters, Table 3) at the $5^{\prime}$ end of the PCR product. Amplification was carried out with Pfu DNA polymerase as recommended by Stratagene by use of pET-rnel as the template. This PCR product was cloned into the Smal site of pU C 18 and sequenced. The plasmid pUC-rnel, constructed as described above (with the $\mathrm{N}$ del-HindlII rne fragment in the opposite sense of Plac), was digested by BamHI and EcoRV, and the excised region was replaced by the BamHI-EcoRV fragment carrying the tyr25am mutation. A BamHI-HindlII rne fragment was purified and ligated together with the HindlII-Xhol carboxy-terminal rne fragment (from the pGEM-rneD plasmid) into the pFC13 vector digested by BamHI-Xhol. The resulting plasmid named pFCrne was used to introduce the amber mutation on the chromo-

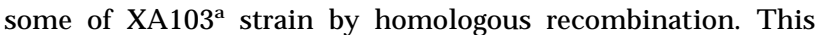
strain has a thermosensible phenotype provided by the ams allele and carries a constitutive supF suppressor. After transformation, the sel ection steps were as described previously (Cornet et al. 1994). Only recombinants carrying the amber allele were able to grow at $42^{\circ} \mathrm{C}$. The tyr25am mutation was transferred into PB4144 strain by P1 transduction by use of the Tn10 marker that is linked to the rne loci. A tetracycline-resistant transductant with a thermosensible phenotype at $42^{\circ} \mathrm{C}$ was selected and the presence of the amber mutation was confirmed by PCR amplification and sequencing. A recA- derivative of this strain was constructed by $\mathrm{P} 1$ transduction by use of GY 8382 strain as the donor (Sommer et al. 1998). The recA- phenotype was checked by sensitivity to UV irradiation. This strain was named PBRN 1.

\section{Construction of deletions within the rne gene}

The pAM-rne plasmid was constructed as follows. A Pstl-Pstl chromosomal fragment encoding the entire RN ase E protein was cloned into the Pstl site of pGB2-derived plasmid pAM 238 (Churchward et al. 1984) containing a polylinker upstream of the lac promoter (J.-P. Bouché, unpubl.) and the ampicillin resistance gene. All rne internal del etions were generated by use of inverse PCR (Hemsley et al. 1989). In each PCR reaction, the pAM-rne plasmid was amplified with primer sets located back to back on the rne sequence. The upstream oligonucleotides used to construct Rne $\Delta 10$ and Rne $\Delta 11$ were rne3069 and rne2064, respectively, and the downstream oligonucl eotide was rne3676 (Table 3). For Rne $\Delta 12$, the oligonucleotides were rne2064 and rne2422. For Rne $\Delta 15$, the oligonucleotides were rne1192 and rne3676. The upstream primers for Rne $\Delta 13$, Rne $\Delta 14$, Rne $\Delta 16$, and Rne $\Delta 18$ were rne2064, rne2445, rne2754, and rne2721, respectively. The same downstream primer, rne3076, was used for these del etions. PCR to amplify long templates was performed as in Cheng et al. (1994) except that Taq (A ppligene) and Pfu DN A polymerase (Stratagene) were used in a ratio of 2.5-0.05 units. PCR products were gel purified, 3 '-end blunted and $5^{\prime}$-end phosphorylated with T4 DNA polymerase and T 4 polynucleotide kinase (Biolabs), self-ligated, and used to transform DH5 $\alpha$. Two independent clones, containing the appropriate deletion, complementing the PBRN 1 strain at $42^{\circ} \mathrm{C}$ 
and expressing a mutant protein of the correct size, were further analyzed in the coimmunopurification experiments. In each case, both clones gave the same result and only one is presented in Figure 3.

Immunopurification of the RNA degradosome from the PBRN 1 strain

Cultures $(100 \mathrm{ml})$ were grown at $42^{\circ} \mathrm{C}$ to stationary phase. Partially purified protein extracts were prepared as described above for the overexpressed degradosomal proteins. The ammonium sulfate pellets were suspended in $200 \mu$ of Buffer A (with 300 $\mathrm{mm} \mathrm{N} \mathrm{aCl}$ throughout this protocol) (Carpousis et al. 1994). The protein concentration was estimated by the optical density at $280 \mathrm{~nm}$.

Anti-RN ase $\mathrm{E}$ or anti-PN Pase antibodies were cross-linked to protein A-Sepharose (Pharmacia) as follows. All incubations were at $4^{\circ} \mathrm{C}$ with gentle agitation. The beads were incubated for $1 \mathrm{hr}$ with the polyclonal rabbit antiserum, washed three times with 10 vol of CLB (cross-linking buffer- $20 \mathrm{~mm} \mathrm{Na}_{2} \mathrm{HPO}_{4}, 5 \mathrm{~mm}$ $\mathrm{NaH}_{2} \mathrm{PO}_{4}, 0.2 \mathrm{~mm} \overline{\mathrm{N}} \mathrm{aCl}, 0.5 \mathrm{~mm}$ EDTA), suspended in $5 \mathrm{vol}$ of CLB containing $1 \%$ glutaral dehyde and incubated for another hour, and washed three times with $10 \mathrm{vol}$ of CLB and twice with $10 \mathrm{vol}$ of buffer $A$. These beads were then incubated with $2 \mathrm{mg}$ of protein for $2 \mathrm{hr}$, washed three times with buffer $A$, suspended in $200 \mu$ of SDS-PAGE loading buffer without $\beta$-mercaptoethanol, and heated for $15 \mathrm{~min}$ at $55^{\circ} \mathrm{C}$. These conditions prevented the release of the antibodies. The beads were removed by centrifugation, and the supernatants were boiled for 3 min with $\beta$-mercaptoethanol to denature the proteins completely. Silver staining was performed as in Monod et al. (1997).

\section{Mutagenesis of the RhIB DEAD motif to DKAD}

The mutation was created by oligonucleotide-directed mutagenesis. A PCR product encoding amino acids 159-383 of the RhIB protein was generated with primers rhlB1282R and rhIB607K (see Table 3; the lowercase a shows the substitution that creates the E166K mutation). After cloning, this product was sequenced then substituted for the corresponding BstXIBglll fragment in $\mathrm{pET}-\mathrm{rhlB}$.

\section{Acknowledgments}

For helpful technical advice, we thank Paul Watt (yeast twohybrid system) and Jean-Y ves Bouet (E. coli strain construction). We al so thank M arc Dreyfus, Pascal Lopez, Ben Luisi, Kenneth M cD owall, and M artyn Symmons for discussions about various aspects of this research; Tamas Kiss for critically reading the manuscript; and Pat Dennis, who during the early stages of this work, sequenced the insert in pET11-rhlB and found a PCR induced mutation that was subsequently corrected. C.F.H. is a Howard Hughes International Research Scholar. The research in Toulouse was supported by the CNRS. Additional funding was from the Association pour la Recherche sur le Cancer, the Conseil Régional Midi Pyrénées, the Biotechnology and Biological Sciences Research Council, the Imperial Cancer Research Fund, and the European Union.

The publication costs of this article were defrayed in part by payment of page charges. This article must therefore be hereby marked 'advertisement' in accordance with 18 USC section 1734 solely to indicate this fact.

\section{Note added in proof}

It has been demonstrated, using a Flag-tagged protein, that the carboxy-terminal half of RN ase E (residues 530-1061) is neces- sary and sufficient for the interactions with RhlB, enolase, and PN Pase (V.R. Kaberdin, A. Miczak, J.S. Jakobsen, S. Lin-Chao, K.J. M cD owall, and A. von Gabain. 1998. Proc. Natl. Acad. Sci., in press).

\section{References}

Alberts, B. 1998. The cell as a collection of protein machines: Preparing the next generation of molecular biologists. Cell 92: 291-294.

Anderson, J.S.J. and R. Parker. 1998. The $3^{\prime}$ to $5^{\prime}$ degradation of yeast mRNA is a general mechanism for mRNA turnover that requires the SKI2 DEVH box protein and $3^{\prime}$ to $5^{\prime}$ exonucleases of the exosome complex. EMBO J. 17: 1497-1506.

Belasco, J.G. and C.F. Higgins. 1988. Mechanisms of mRNA decay in bacteria: A perspective. Gene 72: 15-23.

Blum, E., B. Py, A.J. Carpousis, and C.F. Higgins. 1997. Polyphosphate kinase is a component of the Escherichia coli RN A degradosome. Mol. Microbiol. 26: 387-398.

Braun, F., E. Hajnsdorf, and P. Régnier. 1996. Polynucleotide phosphorylase is required for the rapid degradation of the RN ase E-processed rpsO mRN A of Escherichia coli devoid of its 3' hairpin. Mol. Microbiol. 19: 997-1005.

Carpousis, A.J., G. Van Houwe, C. Ehretsmann, and H.M. Krisch. 1994. Copurification of E. coli RN ase E and PN Pase: Evidence for a specific association between two enzymes important in RNA processing and degradation. Cell 76: 889900.

Casarégola, S., A. Jacq, D. Laoudj, G. M CGurk, S. M argarson, M Tempête, V. Norris, and I.B. Holland. 1992. Cloning and analysis of the entire $\mathrm{E}$. coli ams gene. Ams is identical to $\mathrm{hmpl}$ and encodes a $114 \mathrm{kDa}$ protein that migrates as a 180 kDa protein. J. Mol. Biol. 228: 30-40. [Corrigendum 238: 867.]

Cheng, S., C. Fockler, W.M. Barnes, and R. Higuchi. 1994. Effective amplification of long targets from cloned inserts and human genomic DN A. Proc. Natl. Acad. Sci. 91: 5695-5699.

Churchward, G., D. Belin, and Y. Nagamine. 1984. A pSC101derived plasmid which shows no sequence homology to other commonly used cloning vectors. Gene 31: 165-171.

Claverie-Martin, F., M.R. Diaz-Torres, S.D. Yancey, and S.E. Kushner. 1991. A nalysis of the al tered mRN A stability (ams) gene from E. coli. J. Biol. Chem. 266: 2843-2851.

Cohen, S.N. 1995. Surprises at the $3^{\prime}$ end of prokaryotic RNA. Cell 80: 829-832.

Cormack, R.S., J.L. Genereaux, and G.A. M ackie. 1993. RN ase E activity is conferred by a single polypeptide: Overexpression, purification, and properties of the ams/rne hmp 1 gene product. Proc. Natl. Acad. Sci. 90: 9006-9010.

Cornet, F., I. Mortier, J. Patte, and J.M. Louarn. 1994. Plasmid pSC101 harbors a recombination site, psi, which is able to resolve plasmid multimers and to substitute for the analogous chromosomal Escherichia coli site dif. J. Bact. 176: 3188-3195.

de la Cruz, J., D. Kressler, D. Tollervey, and P. Linder. 1998. Doblp (M tr4p) is a putative ATP-dependent RNA helicase required for the $3^{\prime}$ end formation of 5.8s rRN A in Saccharomyces cerevisiae. EMBO J. 17: 1128-1140.

Dunn, S.D. 1986. Effects of the modification of transfer buffer composition and the renaturation of proteins in gels on the recognition of proteins on Western blots by monoclonal antibodies. Anal. Biochem. 157: 144-153.

Ehretsmann, C., A.J. Carpousis, and H.M. Krisch. 1992. Messenger RNA degradation in procaryotes. FASEB J. 6: 31863192.

Gascuel, O. and J.L. Golmard. 1988. A simple method for pre- 
dicting the secondary structure of globular proteins: Implications and accuracy. Comput. Appl. Biosci. 4: 357-365.

Gegenheimer, P. 1990. Preparation of extracts from plants. Methods Enzymol. 182: 174-193.

Gibson, T.J. and J.D. Thompson. 1994. Detection of dsRNAbinding domains in RNA helicase $A$ and Drosophila maleless: Implications for monomeric RNA helicases. Nucleic Acids Res. 22: 2552-2556.

Gietz, D., A. St. Jean, R.A. Woods, and R.H. Schiestl. 1992. Improved method for high efficiency transformation of intact yeast cells. Nucleic Acids Res. 20: 1425.

Golemis, E.A., J. Gyuris, and R. Brent. 1994. Interaction trap/ two hybrid system to identify interacting proteins. In Current protocols in molecular biology (ed. F.M. Ausubel), Vol. 2, 13.14. Wiley, New York, NY.

Gyuris, J., E.A. Golemis, H. Chertkov, and R. Brent. 1993. Cdi1, a human $\mathrm{G} 1$ and $\mathrm{S}$ phase protein phophatase that associates with Cdk2. Cell 75: 791-803.

Hayes, R., J. Kudla, G. Schuster, L. Gabay, P. Maliga, and W. Gruissem. 1996. Chloroplast mRN A 3'-end processing by a high molecular encoded RNA binding proteins. EMBO J. 15: 1132-1141.

Hemsley, A., N. Arnheim, M.D. Toney, G. Cortopassi, and D.J. Galas. 1989. A simple method for site-directed mutagenesis using the polymerase chain reaction. Nucleic Acids Res. 17: 6545-6551.

Huang, H., J. Liao, and S.N. Cohen. 1998. Poly(A)- and poly(U)specific RNA $3^{\prime}$ tail shortening by $E$. coli ribonuclease $E$. Nature 391: 99-102.

Jain, C. and J.G. Belasco. 1995. RN ase E auto-regulates its synthesis by controlling the degradation rate of its own mRN A in Escherichia coli: Unusual sensitivity of the rne transcript to RN ase E activity. Genes \& Dev. 9: 84-96.

Kalman, M., H. M urphy, and M. Cashel. 1991. rhlB, a new Escherichia coli K-12 gene with an RNA helicase-like protein sequence motif, one of at least five such possible genes in a prokaryote. New Biologist 3: 886-895.

Kido, M., K. Yamanaka, T. Mitani, H. Niki, T. Ogura, and S. Hiraga. 1996. RN ase E polypeptides lacking a carboxyl-terminal half suppress a mukB mutation in Escherichia coli. J. Bacteriol. 178: 3917-3925.

Kimura, M., T. Miki, S. Hiraga, T. N agata, and T. Yura. 1979. Conditionally lethal amber mutations in the dnaA region of the Escherichia coli chromosome that affect chromosome replication. J. Bacteriol. 140: 825-834.

Littauer, U.Z. and H. Soreq. 1982. Polynucleotide phosphorylase. Enzymes 15: 517-533.

Mackie, G.A., J.L. Genereaux, and S.K. Masterman. 1997. Modulation of the activity of RNase $E$ in vitro by RNA sequences and secondary structures $5^{\prime}$ to cleavage sites. J. Biol. Chem. 272: 609-616.

Margossian, S.P., H. Li, H.P. Zassenhaus, and R.A. Butow. 1996. The DExH box protein Suv3p is a component of a yeast mitochondrial $3^{\prime}$ to $5^{\prime}$ exoribonuclease that suppresses group I intron toxicity. Cell 84: 199-209.

McDowall, K.J. and S.N. Cohen. 1996. The N-terminal domain of the rne gene product has RN ase E activity and is nonoverlapping with the arginine-rich RN A-binding site. J. Mol. Biol. 255: 349-355.

Miczak, A., V.R. Kaberdin, C.L. Wei, and S. Lin-Chao. 1996. Proteins associated with RN ase $E$ in a multicomponent ribonucleolytic complex. Proc. Natl. Acad. Sci. 93: 38653869.

Milburn, S.C., J.W.B. Hershey, M.V. Davies, K. Kelleher, and R.J. Kaufman. 1990. Cloning and expression of eukaryotic initiation factor 4B CDNA: Sequence determination identi- fies a common RNA recognition motif. EMBO J. 9: 27832790.

Mitchell, P., E. Petfalski, A. Shevchenko, M. Mann, and D. Tollervey. 1997. The exosome: A conserved eukaryotic RNA processing complex containing multiple $3^{\prime}-5^{\prime}$ exoribonucleases. Cell 91: 457-466.

Monod, C., F. Repoila, M. Kutateladze, F. Tétart, and H.M. Krisch. 1997. The genome of the pseudo T-even bacteriophages, a diverse group that resembles T4. J. Mol. Biol. 267: 237-249.

Mudd, E.A., H.M. Krisch, and C.F. Higgins. 1990. RN ase E, and endoribonuclease, has a general role in the chemical decay of Escherichia coli mRNA: Evidence that rne and ams are the same genetic locus. Mol. Microbiol. 4: 2127-2135.

Nierlich, D.P. and G.J. Murakawa. 1996. The decay of bacterial messenger RNA. Prog. Nucleic Acids Res. Mol. Biol. 52: 153-216.

Pause, A. and N. Sonenberg. 1992. Mutational analysis of a DEAD box RNA helicase: The mammalian translation initiation factor elF4A. EMBO J. 11: 2643-2654.

Portier, C. 1975. Quaternary structure of polynucleotide phosphorylase from E. coli: Evidence for a complex between two types of polypeptide chains. Eur. J. Biochem. 55: 573-585.

Py, B., H. Causton, E.A. Mudd, and C.F. Higgins. 1994. A protein complex mediating mRNA degradation in Escherichia coli. Mol. Microbiol. 14: 717-729.

Py, B., C.F. Higgins, H.M. Krisch, and A.J. Carpousis. 1996. A DEAD-box RNA helicase in the Escherichia coli RNA degradosome. Nature 381: 169-172.

Raynal, L.C., H.M. Krisch, and A.J. Carpousis. 1996. Bacterial poly(A) polymerase: An enzyme that modulates RNA stability. Biochimie 78: 390-398.

Rozen, F., I. Edery, K. Meerovitch, T.E. Dever, W.C. Merrick, and N. Sonenberg. 1990. Bidirectional RN A helicase activity of eucaryotic translation initiation factors $4 \mathrm{~A}$ and 4B. Mol. Cell. Biol. 10: 1134-1144.

Sambrook, J., E.F. Fritsch, and T. Maniatis. 1989. Molecular cloning. Cold Spring Harbor Laboratory Press, Cold Spring Harbor, NY.

Schmid, S.R. and P. Linder. 1992. D-E-A-D protein family of putative RN A helicase. Mol. Microbiol. 6: 283-292.

Sommer, S. , F. Boudsocq, R. Devoret, and A. Bailone. 1998. Specific RecA amino acid changes affect RecA-U muD'C interaction. Mol. Microbiol. 28: 281-292.

Soreq, H. and U.Z. Littauer. 1977. Purification and characterization of polynucleotide phosphorylase from Escherichia coli. J. Biol. Chem. 252: 6885-6888.

Spring, T.G. and F. Wold. 1971. The purification and characterization of Escherichia coli enolase. J. Biol. Chem. 246: 67976802.

Taraseviciene, L., G.R. Björk, and B.E. Uhlin. 1995. Evidence for an RNA binding region in the Escherichia coli processing endoribonuclease RNase E. J. Biol. Chem. 270: 2639126398.

Xu, F. and S.N. Cohen. 1995. RN A degradation in Escherichia coli regulated by $3^{\prime}$ adenylation and $5^{\prime}$ phosphorylation. $\mathrm{Na}$ ture 374: 180-183. 


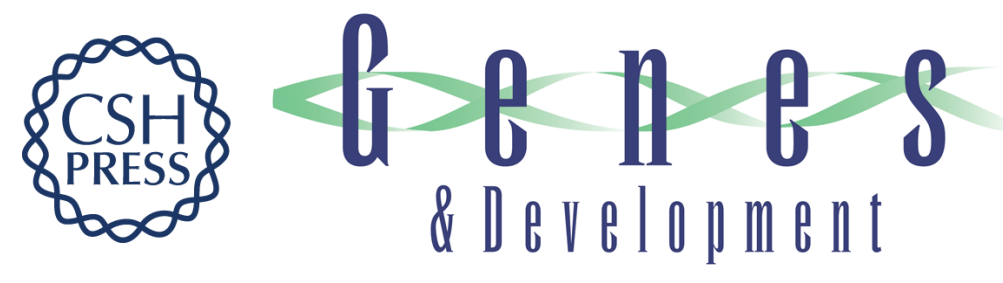

\section{Ribonuclease E organizes the protein interactions in the Escherichia coli RNA degradosome}

Nathalie F. Vanzo, Yeun Shan Li, Béatrice Py, et al.

Genes Dev. 1998, 12:

Access the most recent version at doi:10.1101/gad.12.17.2770

References

This article cites 50 articles, 15 of which can be accessed free at:

http://genesdev.cshlp.org/content/12/17/2770.full.html\#ref-list-1

\section{License}

Email Alerting

Receive free email alerts when new articles cite this article - sign up in the box at the top

Service right corner of the article or click here.

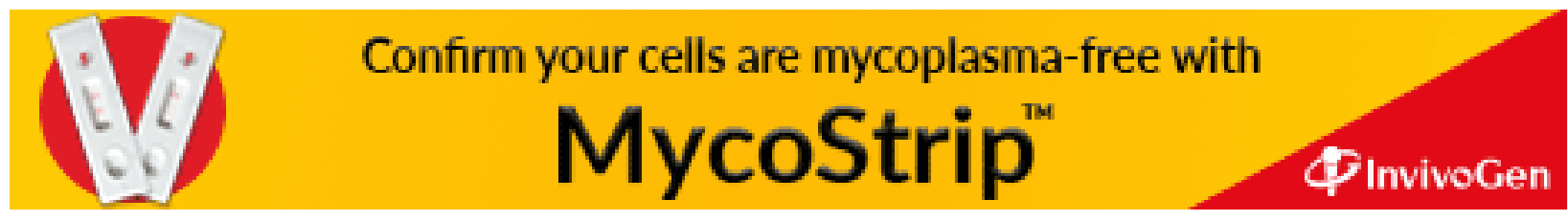

